Article

\title{
"E-tivities from the Front Line": A Community of Inquiry Case Study Analysis of Educators' Blog Posts on the Topic of Designing and Delivering Online Learning
}

\author{
Phemie Wright \\ University of Southern Queensland, West St, Toowoomba QLD 4350, Australia; \\ E-Mail:pw@phemiewright.com.au; Tel.: +61-0889467554
}

Received: 5 February 2014 / Accepted: 7 April 2014 / Published: 22 April 2014

\begin{abstract}
Designing and implementing successful online learning has been at the forefront of institutional agendas since digital learning increased in market demand over the last decade. However there is still ongoing debate as to the "how" of this arduous task. The Community of Inquiry (CoI) is one learning design method that has seen potential in the field, but practical implementation of designing for the important components of Social, Cognitive and Teaching Presence have yet to be fully realised. This paper researches an e-learning design strategy called E-tivities as a suggested possible method for designing for $\mathrm{CoI}$ components. The research explored recent online blog posts of experienced learning designers' and educators' experience in designing successful online learning using E-tivities. Results suggest the E-tivities do have the potential to cater for all Presences of CoI. Specifically when using E-tivities to design online learning Affective Expression was the highest reported Social Presence design factor. All four components of Cognitive Presence appeared to be present in E-tivities design. The most important component for adequate Teaching Presence factors was the initial Design and Organisation of the course. E-tivities and the 5-Stage Model provides a solid framework for this to occur.
\end{abstract}

Keywords: online learning design; E-tivities; e-Moderation; 5-Stage Model; communities of inquiry; Social Presence; Teaching Presence; Cognitive Presence 


\section{Introduction}

Global institutional implementation of online learning is no longer an area dominated by "early adopters", and as such all educators now face the common pressure of effectively adapting their current teaching ideologies and practice to converge with rapidly expanding digital tools and expectations for learning and teaching [1]. They must also negate the complexities surrounding the current disruptive and unstable climates of online education and institutional economic security [2]. Administrators of institutions are increasingly aware of trying to find effective strategies for motivating this "next wave" adoption of online learning and teaching [3]. Although research supports the implementation of constructivist and learner-centred pedagogy for online learning success [4], many educators cite difficulties in adapting their current traditional teaching methods to these theoretically complex approaches [5]. The purpose of this research is to seek to analyse a particular learning design methodology known as E-tivities [6], with an interest in exploring these strategies in comparison to the Community of Inquiry (CoI) design framework [7], as a commonly cited and recommended constructivist design theory. This research therefore explores whether E-tivities (and its associated constructs of e-Moderation and the 5-Stage Model) has the potential to provide a clear learning design framework for Social, Teaching and Cognitive Presence factors in the CoI framework. It also seeks to conceptualise the "how", by drawing on the experience and expertise of practitioners currently using these Salmon design strategies "E-tivities" [6] are based on constructivist and social learning principles, and are cited as a learning design methodology that is neither wholly daunting, or overly arduous [8]. The issue is that although there is some research into the outcomes of applying these particular designing strategies [9-12], very little research or literature is available regarding practical design advice or how-to's for implementing these strategies. Further, there is no research reviewing the connection between E-tivities and CoI with clear designing insights and strategies. This is relevant because the CoI approach has theoretically being successful for designing online learning to meet student satisfaction and, more importantly, retention in online learning $[13,14]$. However, the research available on using $\mathrm{CoI}$ for e-learning design often does not provide clear designing strategies and examples with first-hand experience from diverse learning designers. This research will focus on recent online blog posts that explore learning designers' and educators' experience and recommendations in designing successful online learning using E-tivities. The "bloggers" are not only individuals who have employed E-tivities in their online learning and teaching design for a substantial portion of their educating careers. They are also some of the most successful learning designers and educational experts on the topic of online learning around world today.

\subsection{Research Proposal}

The objective of this research is explore if the online learning design strategies of E-tivities, and subsequent associations of e-Moderation and the 5-Stage Model, may provide a clear methodology for applying the CoI theoretical framework in designing online learning. From a case study approach, this research will explore the participant blog data for designing themes and exemplars for Social, Cognitive and Teaching presence strategies.

The overarching research proposal is: 
How might E-tivities, e-Moderation and the 5-Stage Model be applicable and designed to cater to Social, Cognitive, and Teaching Presence categories of the Community of Inquiry framework?

Therefore the main research questions being investigated are:

1. Are there key principle advice given for designing E-tivities in general that might be useful for future online educators?

2. How might E-tivities, e-Moderation, and the 5-Stage Model be applicable and designed to cater for Social Presence?

3. How might E-tivities, e-Moderation, and the 5-Stage Model, be applicable and designed to cater for Teaching Presence?

4. How might E-tivities, e-Moderation, and the 5-Stage Model, be applicable and designed to cater for Cognitive Presence?

\subsection{Definitions of Special Terms}

E-tivities are defined as "frameworks for enabling active and participative online learning by individuals and groups" [6](p. 5), and are utilised in online learning in order to create a clear structured opportunity for learners to participate and interact collaboratively with the content, peers and the emoderator. They are utilised as a means of seeking and acquiring a deeper understanding and connection to the content of the learning. The foundations of E-tivities include constructivism, situated learning and social learning theories [6,15], which are integral components in "well rehearsed, principles and pedagogies for learning" [6] (p. 1). E-tivities are utilised weekly and consistently through course modules, are recommended to be deployed in groups of 25 people maximum [15], and have a very distinct structure in their design. Please see Salmon (2013) page 3 for an overview of the structure of an E-tivity.

E-Moderation [16,17] is a term used to describe a particular strategy of interaction between the online instructor and their students. According to Salmon [16] the role of the e-moderator is described as "promoting human interaction and communication through the modelling, conveying and building of knowledge and skills" (p. 4). E-moderating skills [16,17] include the use of weaving (integrating online student responses and probing, or questioning areas of further discussion - particularly through the use of E-tivities), and summarising - a succinct summary of learners' responses to the module topic discussions, that explores the deeper context of learners responses and knowledge acquisition. An e-moderator is expected to be sensitive to the online learner's experience and have high levels of emotional intelligence. An e-moderator should display "self-awareness, interpersonal sensitivity and the ability to influence" [17] (p. 104). Emphasising the constructivist principles of quality, personal and effective interactivity between the learner and teacher. See Salmon [17] (p. 206) and Salmon [6] (p. 184), for an overview of weaving and summarising strategies in e-Moderation.

The 5-Stage Model [17] is a scaffolded approach based on extensive research by Salmon, that structures course content and interaction around a natural stage-by-stage learning process the elearner will naturally progress through in online learning, if courses are designed well. The model therefore provides the course designer a scaffold in which to design course content and structure, with the integration of specific stage appropriate E-tivities to meet the individual online pedagogy needs of the learner $[16,17]$. This links directly to providing a valid strategy for meeting learner satisfaction in 
Course Structure and Organisation (CSO) factors. Figure 1 displays a direct image replication of the model and the information of the stages involved from Professor Salmon's (2014) website.

Figure 1. Salmon [17] 5-Stage Model [18].

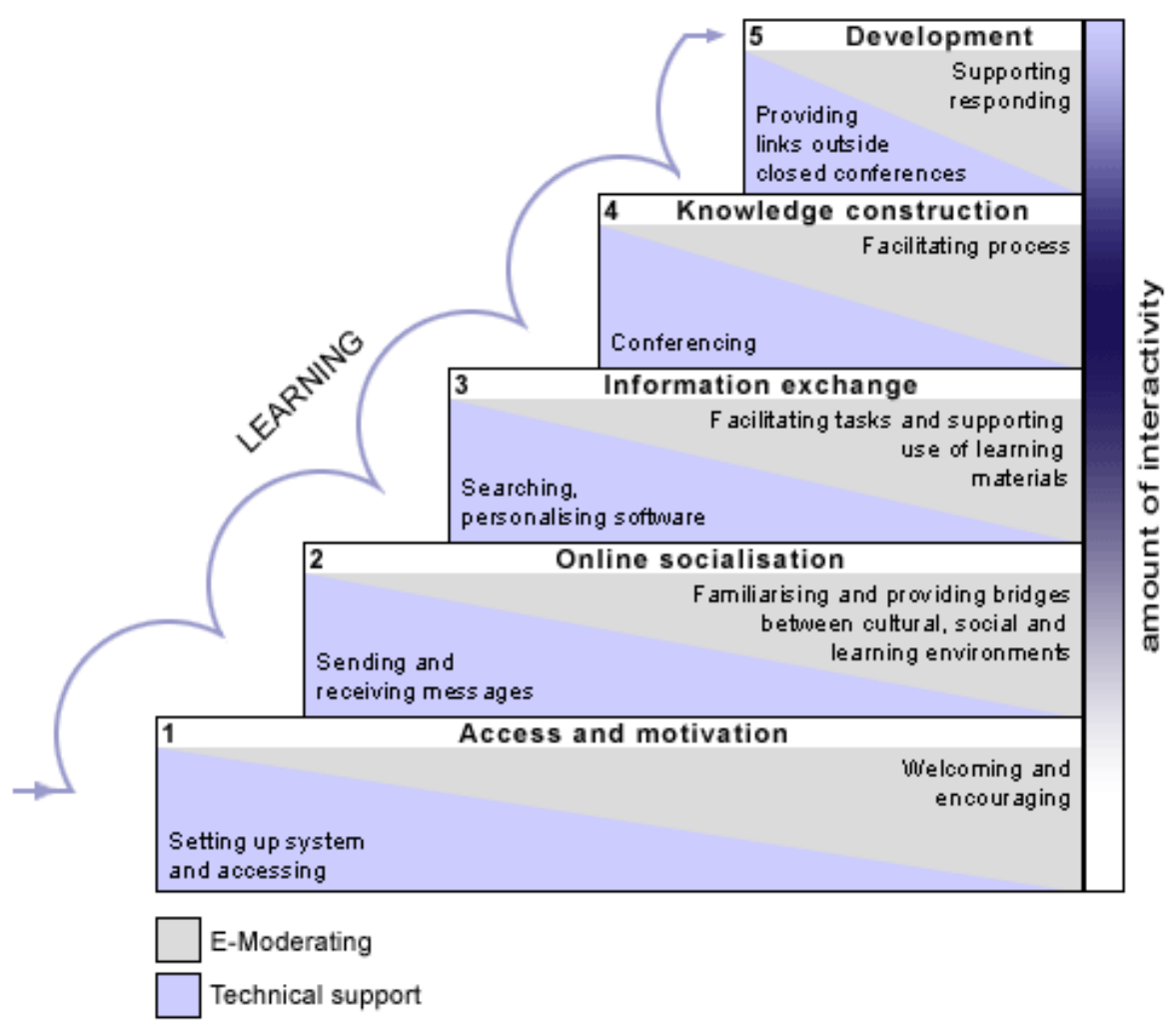

\section{Experimental Section}

\subsection{Methodology}

This study utilised a qualitative method approach, which is an approach that is more interpretive and descriptive analysis of data [19,20] over quantitative and empirical methods (with an emphasis on numerical and statistical data) for defining, measuring and predicting variable outcomes [21,22]. Qualitative methods believe they can make inferences about the "why" or the "how" of the phenomena by being descriptive and exploratory in nature, and have been described as naturalistic or ethnographic [20,23]. They argue that research is "value bound, that it is impossible to differentiate fully causes and effects, that logic flows from specific to general... and that the knower and known cannot be separated because the subjective knower is the only source of reality" [24] (p. 14). As educational research is human specific, with ongoing debate about the ability and appropriateness of defining and measuring output, qualitative analysis provides a fair platform from which to explore the complexities of online educational design, as this research intends to.

\subsection{Sampling and Data Collection}

The study was a purposive sample (as a non-representative subset of a larger population) of online learning designers and educators. The research applied a case study approach, selecting and analysing 
a series of publically accessible blog posts as data, which were put online mid 2013. This was during a "blog project" over the course of five months on the topic of designing E-tivities (and their ubiquitous associations with e-Moderation and the 5-Stage Model). The blog posts contained experiences, advice and resources of educators who currently utilise E-tivities to design and deliver online learning. The publically accessible and ongoing blog posts involved a diverse range of participants across disciplines, roles, and areas of expertise (see http://www.gillysalmon.com/1/category/guest $\%$ 20blogger/1.html). The participants were not formally recruited for this research given the main source of data was publically available online in the form of blog post content. However, consent to utilise these data was made through professional contact networks, and was obtained formally from "blog post authors", giving them an opportunity as to whether to include their blog posts within the analysis.

It is important to note that the use of blogging content as data for research in the social sciences is a relatively new platform, on which there is much debate. A blog is a "form of internet communication in which the author writes dated entries that appear in reverse order (i.e., earliest first) that can link to other webpages and that usually allow readers to comment" [25] (p. 1). Blog data is being increasingly used in social sciences research for a number of reasons. As Hookway [26] explains:

Blogs offer substantial benefits for social scientific research providing similar, but far more extensive opportunities than their "offline" parallel of qualitative diary research. First, they provide a publicly available, low-cost and instantaneous technique for collecting substantial amounts of data. Further, blogs are naturalistic data in textual form, allowing for the creation of immediate text without the resource intensiveness of tape recorders and transcription (p. 92).

Blog data was used for this particular study for a number of reasons. Firstly, there was an issue of time constraints and participant availability on the topic and pre-available blog data provided a solution to this. Secondly, as there was no research that compared Salmon strategies to the CoI framework, the researcher wanted to focus this investigation as finding preliminary connections, so that a future argument might support funding or research to investigate this phenomenon further. The availability of publically assessable blog data, that specifically discussed how educators designed and used these Salmon strategies, provided a readily available and content relevant platform from which to start research in this field. In addition, given the fact that blogging is reflective in nature, and reflective writing allows for metacognitive processes to prevail [27], it is likely that participants' responses may well provide richer and more meaningfully content to explore than traditional qualitative data collection methods. As a case study, the participants' blog post entries were copied and pasted into individual word documents, de-identified and then saved as separate participant content data on a secure password protected USB. This data was subsequently uploaded into NVivo (10.0) software for coding and analysis.

\subsection{Participants}

A total of nine participants (six female and three male) out of the nine blog posts gave their consent for their blog post data to be analysed. No demographical data was outlined in the blog posts besides the participants' current industries, locations and positions. Questions relating to other background 
information were addressed differently with each participant, depending on the month's topic "theme", and were open to participants to answer in their own way (e.g., "Please list your Background/BIO (as you would like it included on the website) and Please tell us a little bit about yourself and your relationship to E-tivities"). Therefore, the content was not consistent across all participants. Table 1 on the following page gives a randomised order breakdown of the nine participants at a glance.

\subsection{Procedure for Data Analysis}

The content of the blog posts were coded and analysed following Wellington's [28] adaptation of the constant comparison method with the "continuing refinement of categories" data analysis strategy as outlined in Figure 2 below.

Figure 2. The "Constant Comparison Method" and "Continual Refinement" of categories. Source Wellington [28] (p. 137).

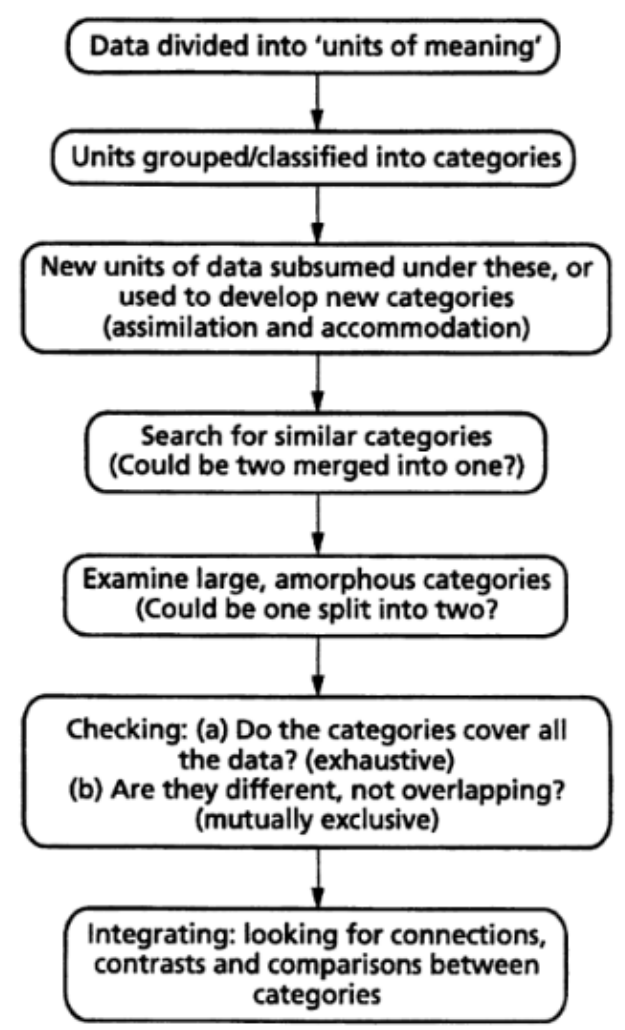

The coding of the data content was approached from a "middle-range" procedure, whereby categories for coding can "come from both the data and the literature" [29] (p. 39). The data was micro analysed, using line by line coding methodology, in to manageable units and summaries of the participants' responses, then through continual refinement and constant comparison, content categories began to emerge. Line-by-line coding, as reiterated by Holton [30], has the potential to maximalise missing integral categories that emerge from the data specifically.

Initially three overarching content categories emerged from the data:

1. Reasons for using E-tivities;

2. Benefits and Outcomes of using E-tivities; and

3. Challenges for Designing E-tivities. 
Table 1. Participants' demographics and background at a glance.

\begin{tabular}{|c|c|c|c|c|c|c|}
\hline Participant & Gender & Current position & Location & Industry & Years with E-tivities & Previous relevant experiences \\
\hline Participant 1 & Female & $\begin{array}{l}\text { Founding Director: E-learning } \\
\text { Consulting Business }\end{array}$ & Denmark & $\begin{array}{l}\text { E-learning Training/Private } \\
\text { Enterprise }\end{array}$ & 11 years & $\begin{array}{l}\text { M.A. in Pedagogy and e-learning Learning Designer in } \\
\text { (online) Higher Education }\end{array}$ \\
\hline Participant 2 & Female & $\begin{array}{l}\text { Distance Learning Manager } \\
\text { and Teaching Fellow }\end{array}$ & United Kingdom & Higher Education & 8 years & $\begin{array}{l}\text { Taught adult literacy and English as a second language and } \\
\text { trained tutors. Worked as a trainer, writer and skills } \\
\text { development consultant. Led a multimedia curriculum } \\
\text { development team in a large petroleum company }\end{array}$ \\
\hline Participant 3 & Female & $\begin{array}{l}\text { Senior Lecturer-Research } \\
\text { Institute }\end{array}$ & Queensland, Australia & Higher Education- & 13 years & $\begin{array}{l}\text { Many years' experience as an educator in Higher Education, } \\
\text { and a researcher of educational technology }\end{array}$ \\
\hline Participant 4 & Female & Learning Design Manager & Melbourne, Australia & Higher Education & 2 years $*$ & $\begin{array}{l}\text { Academic educational developer, and Program Coordinator } \\
\text { and tutor in the Graduate Certificate in Learning and Teaching } \\
\text { within Higher Education }\end{array}$ \\
\hline Participant 5 & Female & $\begin{array}{l}\text { Learning Technologist \& } \\
\text { Research Fellow }\end{array}$ & United Kingdom & Higher Education & $10+$ years $*$ & $\begin{array}{l}\text { Involved with learning technology and research in the UK } \\
\text { Higher Education context since } 1998\end{array}$ \\
\hline Participant 6 & Female & Academic Dean & Melbourne, Australia & Higher Education & 3years & $\begin{array}{l}\text { Personal experience teaching statistics online, and managed a } \\
\text { faculty delivering a wide range of programs online }\end{array}$ \\
\hline Participant 7 & Male & $\begin{array}{l}\text { e-Convener, E-learning } \\
\text { Training Business }\end{array}$ & United Kingdom & $\begin{array}{l}\text { E-learning Training/Private } \\
\text { Enterprise }\end{array}$ & 15 years & Learning Designer/trainer of online tutors in Higher Education \\
\hline Participant 8 & Male & Academic Developer & United Kingdom & Higher Education & 5 years & Senior Learning Technologist in Higher Education \\
\hline Participant 9 & Male & $\begin{array}{l}\text { Founding Director of } \\
\text { e-Learning Business / Trainer }\end{array}$ & United Kingdom & $\begin{array}{l}\text { E-learning Training/Private } \\
\text { Enterprise }\end{array}$ & 15 years & $\begin{array}{l}\text { Maths teacher, computer systems analyst, managed training } \\
\text { for an IT department, and was an Associate lecturer of a } \\
\text { Business faculty (Online Higher Education) }\end{array}$ \\
\hline
\end{tabular}

* Not directly answered, interpreted from other background comment. 
Line-by-line content was consequently summated into a simplified sentence or concept to represent the idea being put across, in order to match it with its appropriate category. As an example of the line-by-line coding process can be seen in the following two statements:

- "encourages quick focus on learning rather than having to cope with the peculiarities of the software platform"; and

- "as they are able to focus on the important issues in the courses and avoid being distracted by the IT aspects."

These statements were eventually coded as "Focus on learning, not technology", and were appropriate to the overarching category "Benefits of E-tivities".

Three further categories that were established from the literature reflected the researcher's interest in exploring the CoI elements. These further categories were:

1. Social Presence;

2. Cognitive Presence; and

3. Teaching Presence.

In order to analyse for specific key indicators of the CoI presences without previous similar research, further sub categories with the presences were created, influenced and based on the category refinements within the original literature, and the CoI Survey Instrument (draft v15). This CoI Survey was developed by Ben Arbaugh, Marti Cleveland-Innes, Sebastian Diaz, Randy Garrison, Phil Ice, Jennifer Richardson, Peter Shea, and Karen Swan [13,31]. Refer to Table 2 below for the sub categories of CoI.

Table 2. Sub categories of Community of Inquiry (CoI) presences.

\begin{tabular}{|l|l|l|}
\hline Social Presence & Cognitive Presence & Teaching Presence \\
\hline Affective Expression & Triggering Event & Design and Organisation \\
Open Communication & Exploration & Facilitation \\
Group Cohesion & Integration & Direct Instruction \\
& Resolution & \\
\hline
\end{tabular}

In order to explore where these CoI presences might be being catered for in the use of E-tivities, E-Moderation and the 5-Stage Model, data that had been previously coded into general summations were then further reviewed to establish if they aligned with these CoI categories. To do this, the nodes were reviewed using particular key words or descriptors that summarised the design context behind the questions from the CoI survey and insight from the literature review. Table 3 below provides an example of the types of general ideas that were looked out for with regards to designing the individual CoI presences. 
Table 3. "Designing for" summations for individual CoI presences (examples only).

\begin{tabular}{|c|c|}
\hline Social Presence & Designing For \\
\hline $\begin{array}{l}\text { Affective Expression } \\
\text { Open Communication } \\
\text { Group Cohesion }\end{array}$ & $\begin{array}{l}\text { Sense of belonging, emotional connectivity, authentic connection, } \\
\text { social interaction } \\
\text { Online communication, discourse, ease of participation, group interaction } \\
\text { Trust, diversity, differing viewpoints, collaboration }\end{array}$ \\
\hline Cognitive Presence & Designing For \\
\hline $\begin{array}{l}\text { Triggering Event } \\
\text { Exploration } \\
\text { Integration } \\
\text { Resolution }\end{array}$ & $\begin{array}{l}\text { Interest, curiosity, motivation } \\
\text { Relevancy, incentives, diversity, variety, perspectives } \\
\text { Explanation, understand, learning concepts } \\
\text { Practical application, solutions, external, real-life }\end{array}$ \\
\hline Teaching Presence & Designing For \\
\hline $\begin{array}{l}\text { Design and Organisation } \\
\text { Facilitation } \\
\text { Direct Instruction }\end{array}$ & $\begin{array}{l}\text { Course clarity, goals, participation instruction, time, framework } \\
\text { Learning, encouragement, guide, clarification, on task, new concepts, } \\
\text { sense of community } \\
\text { Relevant issues, feedback, timeliness, directions. }\end{array}$ \\
\hline
\end{tabular}

Further analysis included utilising the above keywords in a text search analysis using NVivo, with matches set on synonyms, whereby exact words, stemmed words and synonyms of the words were found, and frequency statistics then reviewed. Figures 3-5 below offer some examples of word text analysis searches

Figure 3. Word text analysis for "Interaction".

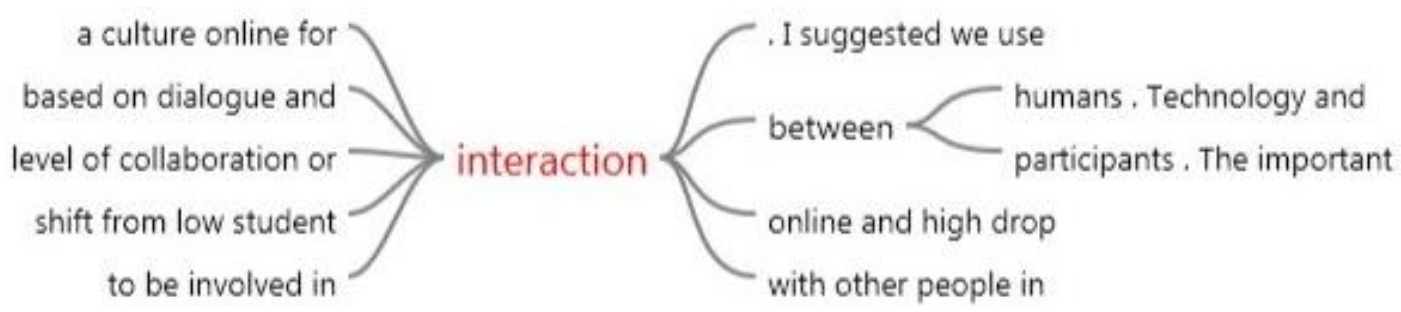

Figure 4. Word text analysis for "Collaboration".

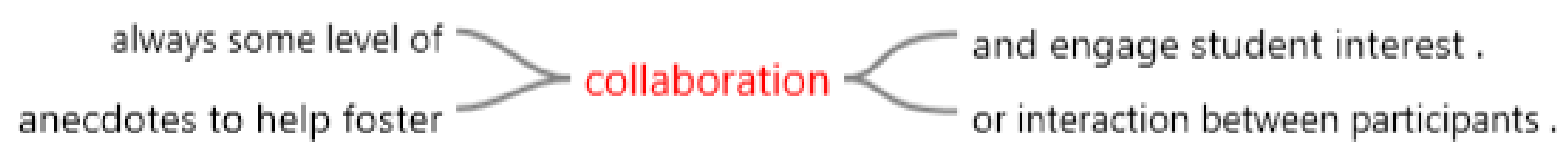

Figure 5. Word text analysis for "Different".

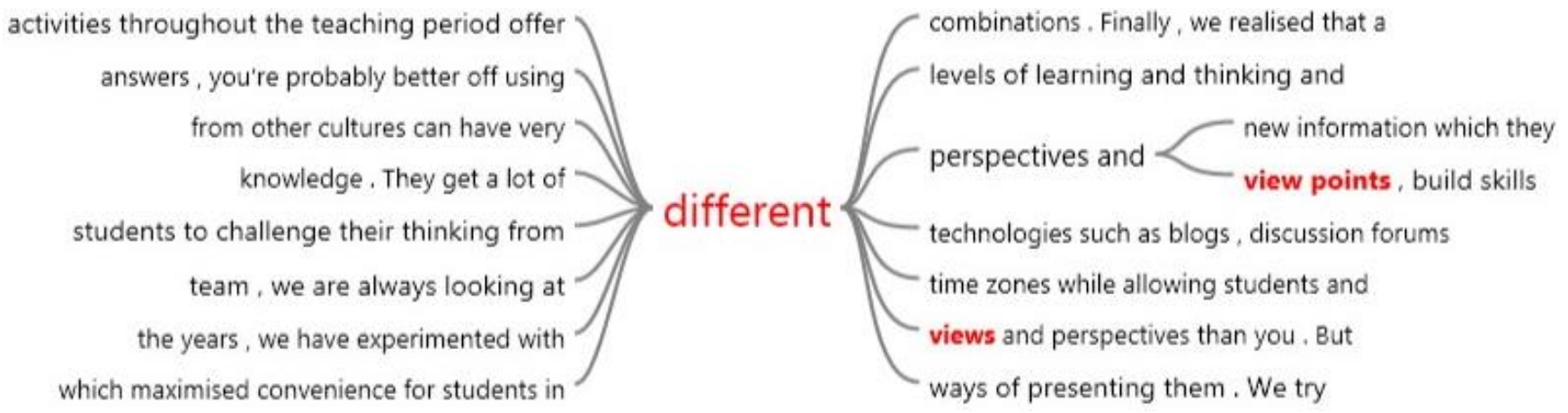


Through this exploration, data could be highlighted and mined for further constant comparison exploration, and creation of category summations, as well as supporting previous node classifications. Coding cluster analysis was run in NVivo, and content percentage was analysed and reported.

\section{Results}

Three sub categories emerged when seeking to answer the research question "Are there key principle advice given for designing e-tivities in general that might be useful for future online educators". These included "Reasons for using E-tivities", "Benefits and Outcomes of E-tivities", and "Challenges of E-tivities". The following is a breakdown of the results that emerged around these three areas.

\subsection{Reasons for Using E-Tivities}

The participants expressed many reasons that they utilised E-tivities, mostly in relation to their previous success with them. Participants were largely exposed to the use of them during institutional change, and their "initiation" into the online learning environment. Participants reported their motivations for using E-tivities, e-Moderation and the 5-Stage Model was a result of their needs and desires for creating quality online learning design, after experiencing previous failures. Table 4 below gives and outline into the reasons reported for using E-tivities, etc., in their learning design.

Table 4. Participants' reasons for using E-tivities for online learning.

\begin{tabular}{|l|l|}
\hline Reasons for using E-tivities $\boldsymbol{e t c}$. & Number of participant responses \\
\hline Adaptable across courses and disciplines & 3 \\
High quality experience & 4 \\
Highly engaging and interactive & 3 \\
Reliable and practical based structure & 3 \\
Same experience (or better) than face to face & 1 \\
Social Constructivist Design & 9 \\
\hline
\end{tabular}

\subsection{Benefits and Outcomes of Using E-Tivities}

There were five overarching benefit categories to come out of the analysis. These five categories and the percentage discussed/reported included Academic Benefit (14\%), Design Benefit (17\%), Pedagogy Benefit (32\%), Social Benefit (21\%), and Student Benefits (16\%). Table 5 below provides a summary of these benefits and the corresponding CoI component that they could be seen to cover. 
Table 5. Overarching Categorical Benefits of E-tivities and their corresponding CoI framework components.

\begin{tabular}{|l|l|l|}
\hline Benefit of E-tivities & Descriptors & Matching CoI component \\
\hline Pedagogy Benefit 32\% & $\begin{array}{l}\text { Research based, well rehearsed, helped face-to-face } \\
\text { teaching, non transactional in nature }\end{array}$ & Cognitive Presence \\
\hline Social Benefit 21\% & $\begin{array}{l}\text { Social Collaborative, enables inclusivity, } \\
\text { developed student networking }\end{array}$ & Social Presence \\
\hline Design Benefit 17\% & $\begin{array}{l}\text { Consistent and organised, easy to understand and } \\
\text { apply, usable across multiple online platforms }\end{array}$ & Teaching Presence \\
\hline Student Benefit 16\% & $\begin{array}{l}\text { High Satisfaction, Engaged Students, } \\
\text { Quick Adaptability }\end{array}$ & Social Presence \\
\hline Academic Benefit 14\% & Lower drop out, higher grades, more participation & Cognitive Presence \\
\hline
\end{tabular}

There were 16 sub-set benefits and outcomes reported in using E-tivities for learning design that dwelled within the five overarching categories. Figure 6 below represents the percentage discussed/reported by participants of different benefits and outcomes, grouped by their categories

Figure 6. Percentage of subset outcomes and benefits of E-tivities reported by participants.

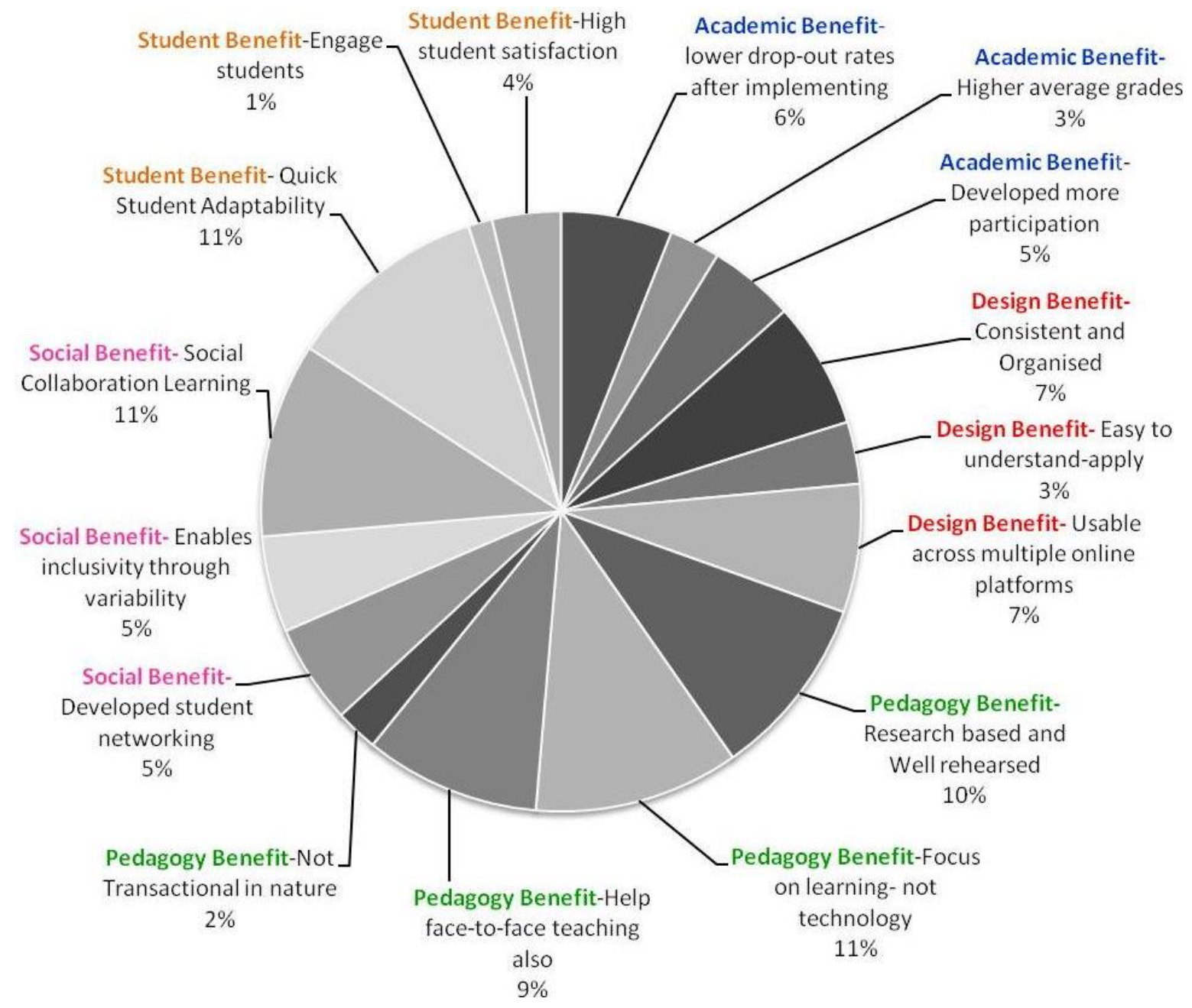


The highest benefits discussed by participants included the two Pedagogy Benefits of E-tivities, being based on research and well rehearsed over its years (11\%), and that E-tivities enabled the focus to be on the learning and not the technology (11\%). Other benefits highly discussed were the Social Benefit of Social Collaboration Learning (11\%), however its category of "social" benefit could be debated, given that research into social collaboration learning design shows benefits of relating to all the categories of social, pedagogy, academic and student. However, given the nature of the theory, it was decided that the social category provided the closest match to the underlying principles of the theory for the purposes of this research. The other highly discussed benefit was the student benefit of how quickly and easily students can adapt to the learning design (11\%). Specifically, as they become familiar with the structure over time, it allows them to not get caught up in the distractions of design and technology, and focus directly on the task at hand.

It is interpreted that Teaching Presence was not equally represented with regard to "benefits" specifically because the main topic of the blog posts were focused on E-tivities and the 5-Stage Model. Rather than e-Moderation which relates to the "teaching" component of Online Leaning, and would therefore be expected to reflect "Teaching Presence".

It is noted that the highest reported benefit was in relation to Pedagogy, which is an important consideration for educators in any industry. It also underpins the principle argument that Salmon [6] makes in regards to these methods providing a practical and step-wise solution for designing for pedagogy that reflects a learner-centred approach, from which all other educational outcomes can achieve success.

\subsection{Challenges for Designing E-Tivities}

All of the participants had their own specific individual and personal challenge in designing E-tivities, with only two participants over-lapping on one particular challenge. Thus, there were eight challenges in total out of nine participants, each challenge reported by a different participant. This could reflect that the constraints and issues relating to online learning design and delivery appear to be situational and content specific, at least in the situation of these participants. Table 6 below outlines the eight key areas that were defined as being the challenges the participants faced in designing E-tivities.

Table 6. Challenges for designing E-tivities as reported by participants.

\begin{tabular}{|l|l|}
\hline Challenges for Designing E-tivities & Number of participant responses \\
\hline $\begin{array}{l}\text { Balance between personal and discipline related content to } \\
\text { generate knowledge sharing }\end{array}$ & 1 \\
\hline $\begin{array}{l}\text { Difficulties with learning to design cross culturally } \\
\text { (designer issues rather than issues with E-Tivities specifically) }\end{array}$ & 1 \\
\hline Hard to predict students experience of an E-tivity & 1 \\
\hline Technology restricted by institution-limits creativity & 1 \\
\hline Unreliable technology make design more time consuming & 1 \\
\hline Stage 1 and 2 crucial to ensure other stages will work & 2 \\
\hline $\begin{array}{l}\text { The importance of feedback on developing E-tivity designs } \\
\text { (hard to do it alone) }\end{array}$ & 1 \\
\hline Challenge of balancing creativity and academic content & 1 \\
\hline
\end{tabular}




\subsection{Social Presence in Design}

In order to answer the research question "How might E-tivities, e-Moderation and the Five-Stage Model, be applicable and designed to cater for Social Presence", text evaluation, and content comparison analysis for Social Presence indicators were reviewed. A number of ideas emerged and these were summated into overarching concepts that grouped themselves naturally into the three categories within Social Presence (Affective Expression, Group Cohesion and Open Communication). The results are demonstrated below in Table 7, along with the percentage that each of the learning design ideas were discussed in relation to the whole topic/indicators of design that aligned with Social Presence. They have also been ordered from most discussed, to least discussed. This table provides a combination of explanations and suggestions that related to designing for factors of Social Presence, but also for how E-tivities have demonstrated (in the participants' experience) an element that could be categorised as Social Presence. Interpretation and possible inferences to be made from these results will be presented in the discussion section.

Table 7. Areas of designing and E-tivities that align with Social Presence indicators.

\begin{tabular}{|c|c|c|c|}
\hline & Affective Expression & Group Cohesion & Open Communication \\
\hline & $\begin{array}{l}\text { Use multiple platforms in designing } \\
\text { enabled connected discourse } \\
17.2\end{array}$ & $\begin{array}{l}\text { Keep your design constant and } \\
\text { connected to the learner } \\
16.26\end{array}$ & $\begin{array}{l}\text { Multimedia approach } \\
\text { provided more options for } \\
\text { conversing and interacting } \\
12.8\end{array}$ \\
\hline & $\begin{array}{l}\text { Voice boards for } \\
\text { Affective expression } \\
9.41\end{array}$ & $\begin{array}{l}\text { E-tivities in Virtual Worlds for } \\
\text { Group Cohesion } \\
10.8\end{array}$ & $\begin{array}{l}\text { Technologies such as Blogs, } \\
\text { email, Skype used for open } \\
\text { communication } \\
8.2\end{array}$ \\
\hline & $\begin{array}{l}\text { Were able to measure the degree of } \\
\text { emotional involvement students } \\
6.8\end{array}$ & $\begin{array}{l}\text { Take time to create a safe } \\
\text { environment } \\
3.92\end{array}$ & $\begin{array}{l}\text { Wikis allow for more reserved } \\
\text { students to participate at a } \\
\text { level comfortable to them } \\
3.6\end{array}$ \\
\hline & $\begin{array}{l}\text { Ability to build groups and develop } \\
\text { authentic connecting } \\
3.17\end{array}$ & $\begin{array}{l}\text { Make the most out of stage } 2 \\
\text { for creating authentic group } \\
\text { connections } \\
2.06\end{array}$ & $\begin{array}{l}\text { E-tivities on discussion } \\
\text { boards have potential for } \\
\text { more detailed communication } \\
2.9\end{array}$ \\
\hline & $\begin{array}{l}\text { Importance of designing for } \\
\text { socialisation before exposing } \\
\text { students to complex technology } \\
2.88\end{array}$ & & \\
\hline Total Percentage & $39.46 \%$ & $33.04 \%$ & $27.5 \%$ \\
\hline
\end{tabular}

\subsection{Cognitive Presence in Design}

In order to answer the research question "How might E-tivities, e-Moderation and the Five-Stage Model, be applicable and designed to cater for Cognitive Presence" text evaluation and content comparison analysis for Cognitive Presence indicators were reviewed. The results are demonstrated below in Table 8 , along with the percentage that each of the learning design ideas were discussed in 
relation to the whole topic/indicators of design that aligned with Cognitive Presence. They have also been ordered from most discussed, to least discussed. This table provides a combination of explanations and suggestions that related to designing for factors of Cognitive Presence, but also for how E-tivities have demonstrated (in the participants' experience) an element that could be categorised as Cognitive Presence. Interpretation and possible inferences to be made from these results will be presented in the discussion section.

Table 8. Areas of designing and E-tivities that align with Cognitive Presence indicators.

\begin{tabular}{|c|c|c|c|c|}
\hline & Triggering Event & Exploration & Integration & Resolution \\
\hline & $\begin{array}{l}\text { Sparks need to be } \\
\text { relevant, not just } \\
\text { decorative }\end{array}$ & $\begin{array}{l}\text { Design with rewards and } \\
\text { incentives for } \\
\text { participation based on } \\
\text { intrinsic and motivation } \\
11.98\end{array}$ & $\begin{array}{l}\text { Using certain technology } \\
\text { (e.g., voice boards) } \\
\text { applied appropriately can } \\
\text { lead to self-instigated } \\
\text { learning and developing } \\
\text { new resources } \\
11.01\end{array}$ & $\begin{array}{l}\text { Design for practical, } \\
\text { hands-on applied } \\
\text { learning }\end{array}$ \\
\hline & $\begin{array}{l}\text { Use of imagery to } \\
\text { create a spark of } \\
\text { designing inspiration } \\
6.24\end{array}$ & $\begin{array}{l}\text { E-tivities have to be } \\
\text { considered useful to } \\
\text { participants } \\
7.55\end{array}$ & $\begin{array}{l}\text { Design towards learning } \\
\text { outcomes and assessment } \\
\text { for knowledge } \\
\text { acquisition } \\
7.06\end{array}$ & $\begin{array}{l}\text { Design e-tivities that } \\
\text { reinforce previously } \\
\text { skills (e.g., research) } \\
7.20\end{array}$ \\
\hline & $\begin{array}{l}\text { Importance of } \\
\text { capturing, grabbing or } \\
\text { engaging the } \\
\text { participants interest } \\
3.76\end{array}$ & $\begin{array}{l}\text { Offer diverse activities in } \\
\text { order to enable } \\
\text { participant learning } \\
\text { differences } \\
6.82\end{array}$ & $\begin{array}{l}\text { Oral type activities create } \\
\text { deeper analysis and } \\
\text { understanding } \\
8.14\end{array}$ & $\begin{array}{l}\text { Scaffolded } \\
\text { assessment to skills } \\
\text { acquired } \\
6.41\end{array}$ \\
\hline & $\begin{array}{l}\text { Technology } \\
\text { (info graphics, photos, } \\
\text { videos, music, games) } \\
\text { as sparks enables more } \\
\text { engaged interaction } \\
\text { from the outset } \\
1.17\end{array}$ & $\begin{array}{l}\text { E-tivities have to be } \\
\text { drivers of learning, not } \\
\text { add-ons to it } \\
2.06\end{array}$ & & \\
\hline Total Percentage & $19.65 \%$ & $28.41 \%$ & $26.21 \%$ & $25.73 \%$ \\
\hline
\end{tabular}

\subsection{Teaching Presence in Design}

In order to answer the research question "How might E-tivities, e-Moderation and the Five-Stage Model, be applicable and designed to cater for Teaching Presence", text evaluation and content comparison analysis for Teaching Presence indicators were reviewed. Table 9 on the following page demonstrates the results of Teaching Presence indicators, along with the percentage that each of the learning design ideas were discussed in relation to the whole topic/indicators of design that aligned with Teaching Presence. They have also been ordered from most discussed, to least discussed. This table provides a combination of explanations and suggestions that related to designing for factors of Teaching Presence, but also for how E-tivities have demonstrated (in the participants' experience) an element that could be categorised as Teaching Presence. Interpretation and possible inferences to be made from these results will be presented in the discussion section. 
Table 9. Areas of designing and E-tivities for aligning Teaching Presence indicators.

\begin{tabular}{|c|c|c|c|}
\hline & Design and Organisation & Facilitation & Direct Instruction \\
\hline & $\begin{array}{l}\text { Get feedback on designs } \\
20.47\end{array}$ & $\begin{array}{l}\text { Design for } \\
\text { e-moderator's time } \\
5.21\end{array}$ & $\begin{array}{l}\text { Prepare clear instructions for } \\
\text { technology that has a steep learning } \\
\text { curve (e.g., wikis) } \\
3.27\end{array}$ \\
\hline & $\begin{array}{l}\text { Limit complexity of e-tivities; } \\
\text { or rather keep it simple } \\
13.42\end{array}$ & $\begin{array}{l}\text { Active e-moderators } \\
\text { are integral } \\
3.69\end{array}$ & $\begin{array}{l}\text { Prompt participants to log in regularly } \\
1.69\end{array}$ \\
\hline & $\begin{array}{l}\text { Create an environment that's } \\
\text { logical/consistent to the participants } \\
9.49\end{array}$ & $\begin{array}{l}\text { Relatable and authentic } \\
3.36\end{array}$ & $\begin{array}{l}\text { Use visuals for technological } \\
\text { instructions at Stage } 1 \\
\text { (of the 5-Stage model) } \\
1.27\end{array}$ \\
\hline & $\begin{array}{l}\text { Expect/ensure E-tivities are allowed } \\
\text { to evolve and change } \\
7.57\end{array}$ & $\begin{array}{l}\text { e-Moderator as role } \\
\text { model or coach } \\
2.95\end{array}$ & \\
\hline & $\begin{array}{l}\text { Design effective but time } \\
\text { efficient e-tivities } \\
6.72\end{array}$ & $\begin{array}{l}\text { Approachable and } \\
\text { caring } \\
1.97\end{array}$ & \\
\hline & $\begin{array}{l}\text { Use course objectives to design } \\
\text { wording of E-tivities } \\
4.73\end{array}$ & & \\
\hline & $\begin{array}{l}\text { Test the technology } \\
3.42\end{array}$ & & \\
\hline & $\begin{array}{l}\text { Ensure there is quick access to } \\
\text { knowledge/information for } \\
\text { participants } \\
3.4\end{array}$ & & \\
\hline & $\begin{array}{l}\text { Design for easy navigation } \\
2.89\end{array}$ & & \\
\hline & $\begin{array}{l}\text { Use existing platforms and designs } \\
\text { where possible (e.g., OERs) } \\
2.31\end{array}$ & & \\
\hline & $\begin{array}{l}\text { Utilise mind maps for } \\
\text { designing ideas } \\
2.16\end{array}$ & & \\
\hline Total Percentage & $76.58 \%$ & $17.18 \%$ & $6.24 \%$ \\
\hline
\end{tabular}

\section{Discussion}

With regards to Social Presence results, it can be noted that the highest reported E-tivity designing principles were those that aligned with the Affective Expression (39.46\%). However, Group Cohesion (33.04\%) and Open Communication (27.5\%) were adequately represented also. What is worth noting is the highest percentage design principles within each category. Specifically, it is the E-tivities' ability to be designed and used across multiple platforms that allowed for creating larger discourse opportunities (Affective Expression). Secondly, that in order to design for group cohesion, the most 
commonly mentioned design principle was keeping the design consistent and focused on the learner. E-tivities already have a consistent template for designing which should make this element easier for online educators to cater for. Lastly, the use of multimedia in E-tivity designing was reported by designers to enable more interaction and conversing opportunities amongst learners (Open Communication).

With regards to Cognitive Presence results, interestingly the four indicators of Cognitive Presence categories were relatively evenly distributed. While more examples for designing for Triggering Events and Exploration were given - matching Garrison's [32] comment that these two areas are easier to design and measure for-quality design strategies were discussed for the other two, with design strategies reflecting the role that technology can play in enabling stronger Integration properties such as reflection, explanation and understanding concepts. In addition, it reflects the focus of strategic practical content and design scaffolding that seem to target Resolution principles of practical application, solutions, external and real-life application.

With regard to Teaching Presence results, it is relevant to note that this presence had the highest instances of designing importance discussed even though it had the lowest reported "benefit" of E-tivities - the latter likely to be a reflection of the focus on E-tivities in the blogging topic, rather than e-Moderation, which is Salmon's [17] specific strategy for teaching online. Specifically, the importance of the design and organisation of the course were discussed as the most important teaching factors (76.58\%). This supports Garrison's [32] and Garrison et al. [33] assertion, as supported by the research into this presence over the last decade, on how important this factor is on creating sustainable and successful online learning. As well as the importance of laying the correct foundations from which a successful course, and therefore appropriate teaching presence, cognitive presence and social presence can grow.

\section{Limitations}

Obviously there are limitations of this research from many different avenues, including issues in generalisability outside of this particular case study approach and the small sample size. There are limitations in the qualitative and exploratory research design as being seen as lacking in empirical evidence for a relationship between the variables. Further limitations include issues with the data being pre-existing and not directly written by the participants with any context of CoI applications. However, if you were to consider this in part, an observational approach almost, hearing from designers in the field without influencing their answers or directing their questions towards CoI applications - as would have been likely in a more traditional research design - then there are implications here for findings to have some merit. Specifically given the reflective nature of a blogging platform and potential metacognitive process evolving in the participants' content.

Further limitations have to be considered in the participants' demographics. The majority of the participants are not only supporters of these particular learning and teaching methods, but are considered "experts" (six having 5+ years experience) in the application and design of E-tivities, e-Moderation and the 5-Stage Model. They have many years of experience in the methodologies and have explored them across multiple platforms, contexts, institutions and disciplines. Therefore, it cannot be assumed that more novice designers would be as apt at designing strategies that catered to the CoI framework. It could also be hypothesised that as these experts have been in the industry for so 
long, that they are also well versed and supportive of the CoI framework, and could be organically designing for these components without the influence of the methodology design at all.

\section{Conclusions and Recommendations}

It could be concluded by this research that there is some potential support for an alignment between the CoI framework being operationalised through the use of E-tivities [6], e-Moderation [17] and the 5-Stage Model [6]. This study has shown that there is some possible overlap in learning design strategies. There is some support that if online designers were looking specifically at "how" to design for Social, Cognitive, and Teaching Presence, as per the research questions of this report, that utilising these Salmon specific strategies is likely to be an appropriate approach to take. Specific interesting conclusions that emerged from this study included the potential connection of the use of technology and designing through these strategies, in order to cater to the complexities of Integration and Resolution phases of Cognitive Presence. This is important, given the current research into this area has been unable to not only identify the progression of participants through these phases [34], but that according to Garrison et al. [33], correct learning design strategies for these phases is at the bedrock of this issue. This research has highlighted the potential to utilise these Salmon strategies for catering to this designing issue. The research has also supported Garrison et al. [33] assertion for the importance of a solid learning design strategy that centres around the importance of the teacher and their presence. Research into online learning suggests the most reported area for dissatisfaction/satisfaction in the online learning environment was the quality of the encouragement, feedback, counselling, facilitation, respect and instructional quality of the teacher [35-39]. In other words, their "teaching presence". It is not innovative to suggest the role of the teacher in learning is a pivotal one, and yet online students still continue to be dissatisfied with their experience and their engagement with their teachers. Some research $[40,41]$ suggests that the reason for this is because teachers are often not adequately confident or literate in online teaching skills or pedagogy, and that those with less exposure to online learning have less positive views of its implementation [42]. Further research stressed the importance of continuing exposure to, and education in, online instructing for teachers [38].

With this in mind, it stands to reason that initial recommendations based on this research include training online educators in the strategies E-tivities, e-Moderation, and the 5-Stage Model which would have the potential to not only widen online teachers' capabilities, but potentially target and identify teaching and design capabilities that cater to these integral CoI components. However, in order to truly support this initial hands-on outcome recommendation, additional research specific recommendations would be suggested. These recommendations include the creation of an empirical based study that directly measures the presence of $\mathrm{CoI}$ in these learning and teaching design strategies while they are in action. The best situation of this would be the utilisation of the CoI Survey Instrument (draft v15) [13,31] with participants of courses that are specifically designed with these Salmon methods.

However, putting aside the limitation debate between qualitative and quantitative data collection approaches in research, held most strongly it seems in the social and educational research environments [20], there has still been merit in the current researcher's investigation into this topic. This research has had the potential to shed some light, become a pathfinder even, on not only the complexities of designing online courses that meet the complex criteria of the CoI framework, but also 
simply to highlight the merit and importance in utilising a structured, well-rehearsed and appropriate pedagogy approach to any design of an online course. While one would think this advice stands to reason, the truth is that the current experience of the average online student with their teacher is one of great disappointment $[43,44]$. It is not to say that there are not innovative and passionate educators out there who care about the impact that the design of their online courses will have on their students. The unfortunate truth is that a decade on, the vast majority still do not meet these now scientifically supported conclusions for how to engage and support the online student in the best possible way. As there has been much support for the CoI framework in research for the Presence elements in being important inclusions in online design, this e-learning design strategy is readily available and has the potential to cater to these CoI frameworks. There are even professional development workshops that teach these strategies in a two-day team process event called "Carpe Diem" (see [45,46] for more information about Carpe Diem's). Or alternatively perhaps the developers of the CoI framework, or their own front line supporters, could explore a professional "marriage" between these design theories.

It is not innovative to suggest that teachers in Higher Education should possess the most up-to-date knowledge in their chosen field of expertise. However, perhaps more importantly, they should possess the same level of expertise in effective and innovative delivery of that knowledge to their students [47]. It is the conclusion of this researcher that it is important that Higher Education Institutions continue to pursue the requirement of teaching qualifications for their educators; and at the very least, they should provide ample time and support for educators to participate in professional development training of this nature. As well as ensuring that practical and hands on approaches of the important components of teaching and designing e-learning, form an integral part of the syllabus within the growing number of Graduate Certificates in Higher Education. While this research does not conclude that these Salmon methods are the only teaching and designing methods available that might be appropriate to meet these needs, it does argue and suggest that they are definitely one method worth trying. That, ultimately, it is the passion of this researcher that not just online educators, but the institutions that house them, encourage the implementation of high standards of learning and teaching design in the online environment. If the ultimate goal and argument for the relevancy of higher education in the professional world is that of producing individuals who bear a high standard of training and quality knowledge in their specific discipline, then the expectation is that the institutions should lead this, first and foremost by example. By ensuring that their teachers actually know how to teach, rather than simply being experts in the field that they teach. For one of the key principles in successful knowledge construction within students is how well their educators deliver that knowledge, effectively and inspirationally. Something that the culture of academia seems to have sidestepped, or even worse, appear offended at the very idea that they could be described as a "Teacher". This means however, that administrators of institutions, and indeed the culture of Higher Education needs to consider shifting their focus from research driven rewards and incentives. By, rather, giving adequate support, incentive, rewards, and perhaps most importantly time, for the inspirational educators that are willing to be the representation of the quality training they provide, by ensuring they are appropriately trained themselves. For it is inspirational educators that produce inspirational students, who go out and be the change this world so desperately needs. Which is, after all, at the very least half of the main contribution that Higher Education is meant to be providing to our society in the first place. 


\section{Acknowledgments}

The Author would like to thank those bloggers who were happy to be acknowledged, Anita Monty, David Shepherd, Diane Robbie, Gabi Witthaus, Helen Farley, Ken Giles, Simon Kear, and Terese Bird, for consent to utilise their contributions as data for this project and acknowledge their contribution to the e-learning world. The Author would also like to thank Professor Gilly Salmon for her continued personal and professional support and e-learning opportunities. I am forever, and happily so, in your debt. The Author would lastly like to thank her supervisor of this master's research project, Petrea Redmond, for being her ongoing professional confidant, an inspirational mentor, and for her never-ending ability enjoy the Author's sense of humor.

\section{Conflicts of Interest}

The author declares no conflict of interest.

\section{References}

1. Macdonald, J.; Poniatowska, B. Designing the professional development of staff for teaching online: An OU (UK) case study. Distance Educ. 2011, 32, 119-134.

2. Ernst \& Young. University of the Future: A Thousand Year Old Industry on the Cusp of Profound Change; 2012. Available online: http://www.ey.com/Publication/ vwLUAssets/University_of_the_future/\$FILE/University_of_the_future_2012.pdf (accessed on 6 August 2013).

3. Hixon, E.; Buckenmeyer, J.; Barczyk, C.; Feldman, L.; Zamojski, H. Beyond the early adopters of online instruction: Motivating the reluctant majority. Internet High. Educ. 2012, 15, 102-107.

4. Ruey, S. A case study of constructivist instructional strategies for adult online learning. $B r . J$. Educ. Technol. 2010, 41, 706-720.

5. Chan, S. Designing an online class using a constructivist approach. J. Adult Educ. 2010, 39, 26-39.

6. Salmon, G. E-Tivities: The Key to Active Online Learning, 2nd ed.; Routledge: London, UK; New York, NY, USA, 2013.

7. Garrison, D.R.; Anderson, T. E-Learning in the 21st Century: A Framework for Research and Practice; Routledge/Falmer: New York, NY, USA, 2003.

8. Slevin, J. E-Learning and the transformation of social interaction in higher education. Learn. Media Technol. 2008, 33, 115-126.

9. Bermejo, S. Cooperative electronic learning in virtual laboratories through forums. IEEE Trans. Educ. 2005, 48, 140-149, doi:10.1109/TE.2004.837045.

10. Kovacic, A.; Bubas, G.; Zlatovic, M. E-tivities with a Wiki: Innovative Teaching of English as a Foreign Language. In Proceedings of the EUNIS 2008: VISION IT-Visions for use of IT in Higher Education, 14th Congress of the European University Information Systems Organisation, Aarhus, Denmark, 24-27 June 2008.

11. Morley, D. Enhancing networking and proactive learning skills in the first year university experience through the use of wikis. Nurs. Educ. Today 2012, 32, 261-266, doi:10.1016/ j.nedt.2011.03.007. 
12. Sidhu, R.; Embi, M. Learner e-tivities: Exploring Malaysian learners' roles in asynchronous computer-mediated communication. Eur. J. Educ. Stud. 2010, 2, 157-174.

13. Ice, P.; Gibson, A.M.; Boston, W.; Becher, D. An exploration of differences between Community of Inquiry indicators in low and high disenrollment online courses. J. Asynchronous Learn. Netw. 2011, 15, 44-69.

14. Rubin, B.; Fernandes, R.; Avgerinou, M.D. The effects of technology on the Community of Inquiry and satisfaction with online courses. Internet High. Educ. 2013, 17, 48-57.

15. Salmon, G. E-Tivities: The Key to Active Online Learning; Kogan Page: London, UK, 2002.

16. Salmon, G. E-Moderating: The Key to Teaching and Learning Online, 2nd ed.; Routledge: New York, NY, USA, 2003.

17. Salmon, G. E-Moderating: The Key to Teaching and Learning Online, 3rd ed.; Routledge/Falmer: New York, NY, USA, 2011.

18. Salmon, G. E-Moderating: 5-Stage Model. Available online: http://www.gillysalmon.com/fivestage-model.html (accessed on 30 January 2014).

19. Lodico, M.; Spaulding, D.; Voegtle, K. Methods in Educational Research: From Theory to Practice; John Wiley \& Sons: San Francisco, CA, USA, 2010.

20. Somekh, B.; Burman, E.; Dalamont, S.; Payne, M.; Thorp, R. Research in the social sciences. In Research Methods in Social Sciences, 2nd ed.; Somekh, B., Lewin, C., Eds.; Sage Publication: London, UK, 2011; pp. 2-15.

21. Jones, K. The Practice of Quantitative Methods. In Research Methods in Social Sciences, 2nd ed.; Somekh, B., Lewin, C., Eds.; Sage Publication: London, UK, 2011; pp. 201-211.

22. Mustafa, R.F. The P.O.E.Ms of educational research: A beginners' concise guide. Int. Educ. Stud. 2011, 4, 23-30.

23. Kirk, J.; Miller, M.L. Reliability and Validity in Qualitative Research; Sage Publications: Thousand Oaks, , USA, 1986.

24. Johnson, R.B.; Onweugbuzie, A.J. Mixed-methods research: A research paradigm whose time has come. Educ. Res. 2004, 33, 14-26.

25. Snee, H. Realities toolkit \#10: Using blog analysis; 2010. Available online: http:/eprints. ncrm.ac.uk/1321/2/10-toolkit-blog-analysis.pdf (accessed on 1 October 2013).

26. Hookway, N. "Entering the blogosphere": Some strategies for using blogs in social research. J. Qual. Res. 2008, 8, 91-113.

27. Moon, J.A. Learning Journals: A Handbook for Reflective Practice and Professional Development; Routledge: Oxon, UK, 2006.

28. Wellington, J. Educational Research: Contemporary Issues and Practical Approaches; Continuum International Publishing Group: London, UK, 2000.

29. Urquhart, C. Grounded Theory for Qualitative Research: A Practical Guide; Sage Publications: Thousand Oaks, CA, USA, 2013.

30. Holton, J.A. The coding process and its challenges. In The Sage Handbook of Grounded Theory; Bryant, A., Charmaz, K., Eds.; Sage: London, UK, 2007.

31. Communities of Inquiry. CoI Model. Available online: https://coi.athabascau.ca/coi-model/ (accessed on 30 January 2014). 
32. Garrison, D.R. Online community of inquiry review: Social, cognitive, and teaching presence issues. J. Asynchronous Learn. Netw. 2007, 11. Available online: http://sloanconsortium.org/ $\mathrm{jaln} / \mathrm{v} 11 \mathrm{n} 1 /$ online-community-inquiry-review-social-cognitive-and-teaching-presence-issues (accessed on 19 September 2013).

33. Garrison, D.; Anderson, T.; Archer, W. The first decade of the Community of Inquiry Framework: A retrospective. Internet High. Educ. 2010, 13, 5-9, doi:10.1016/ j.iheduc.2009.10.003.

34. Garrison, D.; Arbaugh, J.B. Researching the Community of Inquiry Framework: Review, issues, and future directions. Internet High. Educ. 2007, 10, 157-172.

35. Bolliger, D.U.; Martindale, T. Key factors for determining student satisfaction in online courses. Int. J. E-Learn. 2004, 3, 61-67.

36. Gunawardena, C.N.; Linder-VanBerschot, J.A.; LaPointe, D.K.; Rao, L. Predictors of learner satisfaction and transfer of learning in a corporate online education program. Am. J. Distance Educ. 2010, 24, 207-226, doi:10.1080/08923647.2010.522919.

37. Kim, K.; Liu, S.; Bonk, C.J. Online MBA students' perceptions of online learning: Benefits, challenges, and suggestions. Internet High. Educ. 2005, 8, 335-344.

38. Paechter, M.; Maier, B.; Macher, D. Students' expectations of, and experiences in e-learning: Their relation to learning achievements and course satisfaction. Comput. Educ. 2010, 54, 222-229.

39. Sher, A. Assessing the relationship of student-instructor and student-student interaction to student learning and satisfaction in web-based online learning environment. J. Interact. Online Learn. 2009, 8, 102-120.

40. Ehrmann, S.C. Why faculty resist. Distance Learn. 2012, 9, 60-64.

41. Schneckenberg, D. Overcoming barriers for eLearning in Universities-Portfolio models for eCompetence development of faculty. Br. J. Educ. Technol. 2010, 41, 979-991.

42. Allen, I.E.; Seaman, J.; Lederman, D.; Jaschik, S. Conflicted: Faculty and online education, 2012.. Available online: http:/www.insidehighered.com/sites/default/server_files/ files/IHE-BSRG-Conflict.pdf (accessed on 12 October 2013).

43. Armstrong, D.A. Students' perceptions of online learning and instructional tools: A qualitative study of undergraduate students' use of online tools. Turk. Online J. Educ. Technol. 2011, 10, 222-226.

44. Lee, S.; Srinivasan, S.; Trail, T.; Lewis, D.; Lopez, S. Examining the relationship among student perception of support, course satisfaction, and learning outcomes in online learning. Internet High. Educ. 2011, 14, 158-163, doi:10.1016/j.iheduc.2011.04.001.

45. Salmon, G.; Wright, P. Transforming Future Teaching through 'Carpe Diem' Learning Design. Educ. Sci. 2014, 4, 52-63, doi:10.3390/educsci4010052.

46. Armellini, A.; Aiyegbayo, O. Learning design and assessment with e-tivities. Br. J. Educ. Technol. 2010, 41, 922-935, doi:10.1111/j.1467-8535.2009.01013.x.

47. Watsona, W.R.; Watsona, S.L.; Reigeluthb, C.M. Education 3.0: Breaking the mold with technology. Interact. Learn. Environ. 2013, 58, doi:10.1080/10494820.2013.764322.

(C) 2014 by the authors; licensee MDPI, Basel, Switzerland. This article is an open access article distributed under the terms and conditions of the Creative Commons Attribution license (http://creativecommons.org/licenses/by/3.0/). 